\title{
Acute Myocardial Infarction and Percutaneous Coronary Intervention: What does the Epidemiological Data of the Last Years Indicate?
}

\author{
Gabriel Silvestre Minucci ${ }^{(1)}$ and Samuel Marques dos Reis ${ }^{(0)}$ \\ Universidade Federal de São João del-Rei, MG - Brazil.
}

\section{Abstract}

Background: ST-segment elevation acute myocardial infarction (STEMI) is a pathological process that involves cardiac muscle tissue death. Intravenous thrombolysis with fibrinolytics or primary percutaneous coronary intervention (PCI), an invasive technique, can be performed for tissue revascularization. $\mathrm{PCI}$ has been preferred as compared to non-invasive methods, although few studies have described its use in Brazil.

Objectives: The aim of the present study was to analyze data on the use of primary PCI and investigate the relevance of hospitalizations for the treatment of STEMI in the country.

Methods: A descriptive, cross-sectional analysis of data from the Brazilian Unified Health system (SUS) Department of Informatics (DATASUS) from 2010 to 2019 was conducted.

Results: Hospitalizations for STEMI represented $0.6 \%$ of all hospital admissions in Brazil in the analyzed period, $0.9 \%$ of hospital costs, and $2.1 \%$ of deaths. The number of hospitalizations due to STEMI was 659,811 , and 82,793 for PCIs. Length of hospital stay was $36.0 \%$ shorter and mortality rate was $53.3 \%$ lower in PCI. The mean cost of PCI was 3.5-fold higher than for treatment of STEMI.

Conclusions: Data on hospitalizations for STEMI treatment in Brazil revealed high hospitalization and mortality rates, elevated costs, and long hospital stay. Although primary PCI is a more expensive and less used technique than other methods, it can reduce the length of hospital stay and mortality in the treatment of STEMI.

Keywords: Cardiovascular Diseases; Myocardial Infarction; Risk Factors; Coronary Diseases; Angioplasty Balloon Coronary/methods; Hospitalization; Mortality.

\section{Introduction}

Coronary artery disease (CAD) is associated with the obstruction of coronary arteries. It has, as an etiopathogenic substrate, atherosclerosis, and as a possible outcome, ischemic syndromes - stable and unstable angina and acute myocardial infarction (AMI). These conditions have varying degrees of impairment involving ischemia and injury, with the possibility that the coronary arteries remain preserved. ${ }^{1}$

AMI is a pathological process that initially affects the coronary arteries and is characterized by tissue death in the cardiac muscle. According to the European Society of Cardiology and the 4 th universal definition of myocardial infarction, the diagnosis of AMI is based on acute changes in cardiac enzyme curves, and evidence of ischemia (clinical condition, electrocardiographic alterations, or abnormal angiography). ${ }^{2} \mathrm{AMI}$ with ST-segment elevation (STEMI) comprises a condition of transmural ischemia involving ST-segment elevation or left bundle-branch block (LBBB) on the electrocardiogram, with acute elevation of cardiac markers due to total occlusion of a segment of the coronary vascular bed. ${ }^{1-3}$ Once STEMI is diagnosed, the course of action to be taken will depend on the resources available at the health care center and the time elapsed since the onset of symptoms. For revascularization of the ischemic tissue, intravenous thrombolysis with fibrinolytic agents as well as primary

Mailing Address: Gabriel Minucci

Praça Dom Helvécio, 74. Postal Code: 36307-352, Fábricas, São João del-Rei, MG - Brazil.

E-mail: gabrielsilcci@gmail.com 
percutaneous coronary interventions (PCIs) ${ }^{3}$ can be carried out.

According to the literature, primary PCI has greater efficacy and better results than fibrinolysis, especially if performed within the first 90 minutes of symptom onset. Despite the similarity with fibrinolytics regarding the need for early intervention for good results, the invasive technique has been preferred over the noninvasive method, ${ }^{4}$ given its association with higher rates of recanalization of the culprit vessel, lower rates of reocclusion and bleeding, in addition to improved ventricular function and survival. ${ }^{4-7}$

However, progress has been made in the treatment for the stabilization of atherosclerotic plaques in the coronary arteries. Studies such as COURAGE2, ISCHEMIA, and CAPTIM have reported similar results concerning drug therapy, percutaneous intervention, and revascularization surgery in prospective follow-up of patients after the acute period..$^{8,9}$

Thus, the main aim of this study was to analyze data on the use of primary PCI as an alternative in STEMI episodes compared with pharmacological treatment in Brazil. The scarcity of data and the importance of this issue justify studies for a better understanding of the Brazilian reality in this regard. Another objective was to investigate factors related to hospitalizations for the treatment of STEMI - total number of hospitalizations, hospitalization costs, and in-hospital mortality.

\section{Methods}

This was a descriptive, cross-sectional study. Data were collected from the "Hospital Admission Authorization" (AIH) form, a document filled out by the physician upon hospital admission recorded in the Hospital Information System (SIH/SUS), available in the free online database of the Brazilian Unified Health System (SUS) Department of Informatics (DATASUS). Data were collected from January to March 2020 and tabulated and analyzed using the TABNET program.

To perform an analysis of a 10-year period, data between January 2010 and December 2019 were examined. We evaluated total hospital admissions in Brazil and hospitalizations for the treatment of ischemic syndromes, STEMI, and for referral for primary coronary angioplasty. The following variables were collected from the records: number of admissions, total hospitalization costs, average cost per admission, mean length of hospital stay, number of deaths, mortality rate, and categories of hospitals by ownership (public - federal, state, and municipal hospitals, or private (contracted by SUS, philanthropic, and union hospitals).

All procedures were classified according to the codes included in the SUS table, maintaining the original nomenclature: 0303060190 - Treatment of Acute Myocardial Infarction; 0303060280 - Treatment of Acute Coronary Syndrome; 0303060204 - Treatment of Arterial Failure with Critical Ischemia; 0406030049 Primary Coronary Angioplasty. Codes 0303060280 and 0303060204 were considered as Ischemic Syndromes.

Since the information was obtained from a public domain database, this study did not need ethics committee approval.

\section{Results}

Data obtained for the period between 2010 and 2019 are described in Table 1.

The rate of hospital admissions over the years can be viewed in the graph below (Figure 1).

When analyzing the data related to the treatment of STEMI, the year with the highest number of admissions was 2019 , with 80,516 hospitalizations, which represented $12.2 \%$ of the total. Overall, there was a $40.2 \%$ growth between 2010 and 2019. The federal state with the highest number of hospitalizations was São Paulo, with 198,593 admissions, corresponding to $30.1 \%$ of all hospital admissions for the treatment of STEMI in the country.

Among the total admissions for STEMI treatment, only $12.5 \%$ were for primary referral for PCI. The highest number of procedures was registered in the year 2019, with 11,099 hospitalizations (13.4\% of the total number of hospital admissions for primary PCI). A $49 \%$ increase in the use of this technique was observed in the analyzed period. The federal state with the highest number of hospitalizations was also São Paulo, with 2,329 admissions, which corresponds to $21.2 \%$ of the total.

Regarding the type of hospital (whether public or private), in $46.7 \%$ of cases the type of hospitalization for the treatment of STEMI was not recorded; $27.4 \%$ $(\mathrm{n}=180,507)$ admissions occurred in public hospitals, and $25.9 \%(n=170,939)$ of hospitalizations took place in the private hospitals. Data on the use of primary PCI indicated that most procedures were performed in the private sector $(31.1 \%$; $n=25,717)$, while $15.3 \%(n=12,699)$ took place in the public sector. Note that in 44,377 (53.6\%) cases, the type of hospital was not recorded. 
Table 1 - Data on hospitalizations for the treatment of ischemic syndromes, myocardial infarction with ST elevation (STEMI), and referral for primary percutaneous coronary intervention in Brazil from 2010 to 2019

\begin{tabular}{|c|c|c|c|c|}
\hline & $\begin{array}{c}\text { Total hospitalizations in } \\
\text { the country }\end{array}$ & $\begin{array}{l}\text { Hospitalizations due to } \\
\text { ischemic syndromes }\end{array}$ & $\begin{array}{l}\text { Hospitalizations for } \\
\text { STEMI treatment }\end{array}$ & $\begin{array}{c}\text { Hospitalizations for } \\
\text { primary coronary } \\
\text { angioplasty }\end{array}$ \\
\hline $\begin{array}{l}\text { Number of } \\
\text { hospitalizations } \\
\left(\mathrm{n}^{\circ}\right)\end{array}$ & $117,122,623$ & $1,573,632$ & 659,811 & 82,793 \\
\hline $\begin{array}{l}\text { Percentage in } \\
\text { hospitalizations * }\end{array}$ & $100 \%$ & $1.34 \%$ & $0.56 \%$ & $0.07 \%$ \\
\hline $\begin{array}{l}\text { Hospital expenses } \\
\text { (Brazilian } \\
\text { currency) }\end{array}$ & $\mathrm{R} \$ 132,996,086,776.43$ & $\mathrm{R} \$ 2,184,781,851.10$ & $\mathrm{R} \$ 1,217,030,068.19$ & $\mathrm{R} \$ 534,204,650.74$ \\
\hline $\begin{array}{l}\text { Percentage in } \\
\text { value spent * }\end{array}$ & $100 \%$ & $1.64 \%$ & $0.91 \%$ & $0.40 \%$ \\
\hline $\begin{array}{l}\text { Number of deaths } \\
\text { (No.) }\end{array}$ & $4,631,633$ & 123,806 & 95,874 & 5,615 \\
\hline $\begin{array}{l}\text { Percentage in } \\
\text { deaths * }\end{array}$ & $100 \%$ & $2.67 \%$ & $2.06 \%$ & $0.12 \%$ \\
\hline Mortality rate & $4.05 \%$ & $6.08 \%$ & $14.53 \%$ & $6.78 \%$ \\
\hline $\begin{array}{l}\text { Average cost } \\
\text { per procedure } \\
\text { (Brazilian } \\
\text { currency) }\end{array}$ & $\mathrm{R} \$ 1,135.44$ & $\mathrm{R} \$ 4,055.65$ & $\mathrm{R} \$ 1,844.54$ & $\mathrm{R} \$ 6,452.29$ \\
\hline $\begin{array}{l}\text { Percentage in } \\
\text { average cost }\end{array}$ & $100 \%$ & $357.18 \%$ & $162.45 \%$ & $568.26 \%$ \\
\hline $\begin{array}{l}\text { Average length of } \\
\text { stay (days) }\end{array}$ & 5.6 & 6.4 & 8.3 & 5.3 \\
\hline $\begin{array}{l}\text { Percentage in } \\
\text { average length } \\
\text { of stay }\end{array}$ & $100 \%$ & $114.28 \%$ & $148.21 \%$ & $94.64 \%$ \\
\hline
\end{tabular}

The mean length of hospital stay for primary PCI was $36 \%$ shorter compared with the duration of hospitalizations for the treatment of STEMI.

Hospital costs for the treatment of STEMI increased by $62.4 \%$ during the analyzed period. The highest hospital costs were observed in São Paulo state, BR\$378,783,670.64, corresponding to $31.1 \%$ of the total national costs, which, in turn, showed a $10.1 \%$ increase over the years. Total hospital expenses for PCI admissions corresponded to $43.9 \%$ of the total costs for the treatment of STEMI, which showed a $101.83 \%$ increase in the analyzed period. Again, the federal state with the highest costs was São Paulo, with BR $\$ 120,791,951.46$, accounting for $14.02 \%$ of the costs with PCI in the country. The average cost per PCI procedure was 3.5-fold higher than that for STEMI treatment, with a $13.87 \%$ increase during the analyzed period.

Regarding mortality rate, the national in-hospital mortality rate for treatment of STEMI reduced by $15.2 \%$ in the period from 2010 to 2019. As for primary PCI, inhospital mortality rate was $53.33 \%$ lower than for STEMI treatment, with a reduction of $17.2 \%$ in the analyzed period.

Of the 1,895 types of hospital procedures described in DATASUS, hospital admissions for the treatment of STEMI occupied the 40th position in terms of number of cases when compared to hospitalizations for primary PCI, which ranked the $175^{\text {th }}$ position. Considering the hospital costs per procedure, costs related to the 


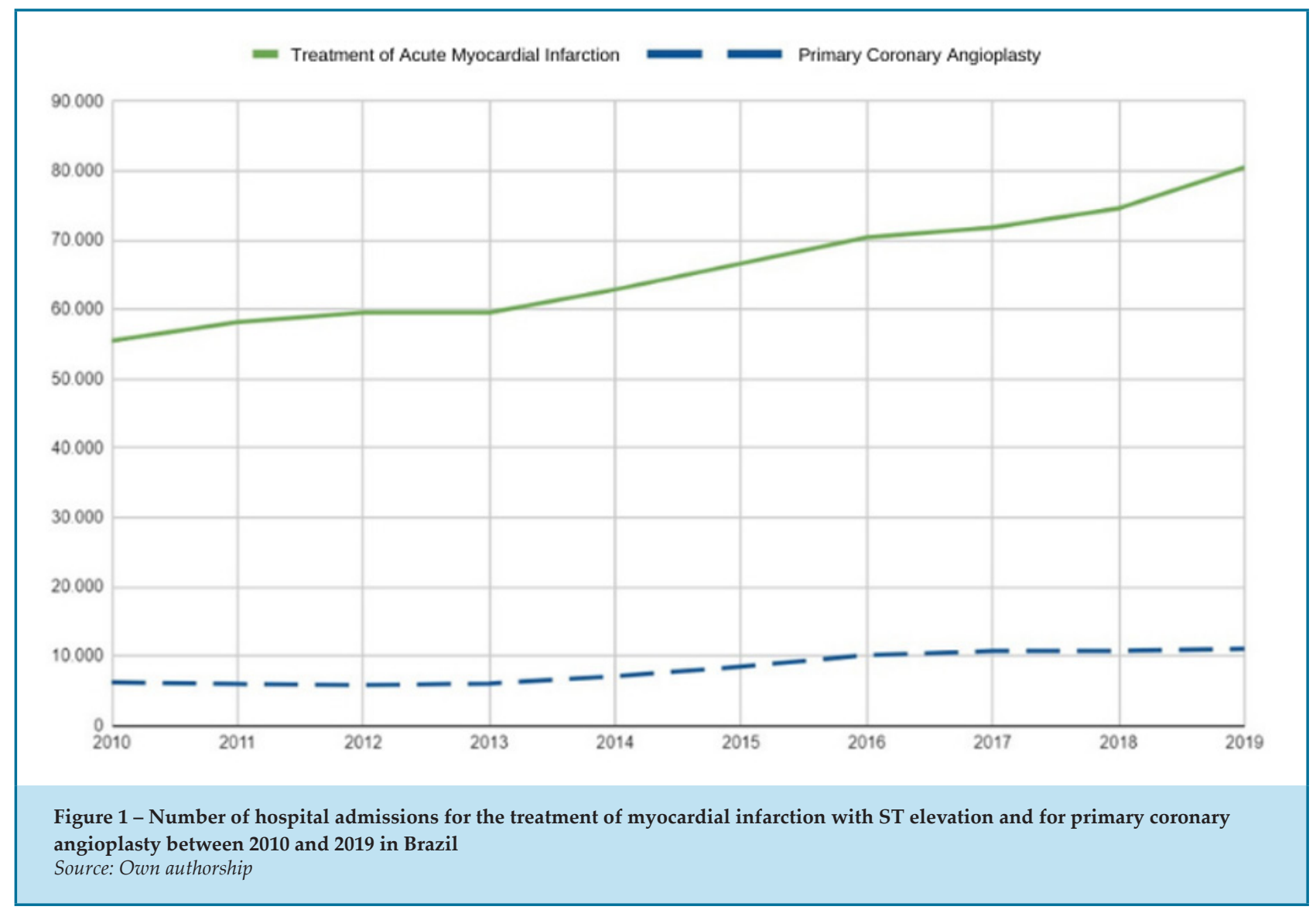

treatment of STEMI was the 26th most expensive in the country, and costs related to PCI occupied the $48^{\text {th }}$ position. In addition, the treatment of STEMI ranked the 9 th position in the number of deaths in the country, and PCI the $88^{\text {th }}$ position.

\section{Discussion}

The data obtained herein evidenced the discrepancy between the numbers of hospital admissions for the treatment of STEMI and for primary coronary angioplasty in the country. Although the number of isolated primary PCI procedure was low, the use of this technique considerably increased in Brazil during the analyzed period, with a growth of 49\% from 2010 to 2019. Such increment can be related to the greater support from scientific literature, investments in the field, refinement of the technique, as well as the larger availability of technology for its use in the country. ${ }^{10,11}$ Nevertheless, this number corresponds to a small percentage of all hospitalizations for the treatment of STEMI during the analyzed period $(12.54 \%)$.
Improvements in the technique and technology, such as the adoption of drug-eluting stents and more potent antiplatelet drugs (including surface glycoprotein IIb/ IIIa receptor inhibitors), also justify the increase in hospitalization costs and supplemental health services in angioplasty interventions. ${ }^{12}$ These advances are accompanied by increasing rates of therapeutic success and reduced mortality. ${ }^{13}$

When compared to fibrinolytics, primary PCI is associated with better short- and long-term clinical outcomes, including greater ability to reestablish coronary flow, and reduced rates of recurrent ischemia, reinfarction, and stroke. Thus, this is the treatment of choice when there is the possibility of transferring the patient to a hospital capable of performing this procedure, ${ }^{5,14-17}$ and should be preferably performed within 90 minutes after the diagnosis of STEMI., ${ }^{5,16-18}$

North American studies with registries from the National Registry of Myocardial Infarction (NRMI) 1,2 , and 3, reported a significant increment in the use of angioplasty compared with fibrinolytics, and a concomitant decrease in morbidity and mortality of 
patients with sustained STEMI. This is related to advances in technology and interventional cardiology, justified by investments in technology and greater experience of the medical teams in countries like the United States. ${ }^{19}$

The growing use of primary PCI in Brazil has been observed since the late 1990s. ${ }^{12}$ In a Brazilian study published in 2010, Piegas and Haddad ${ }^{11}$ conducted a data survey and showed an increasing performance of $\mathrm{PCI}$ in Brazil, with some referral centers presenting mortality rates comparable to international values. ${ }^{11,14}$

In the study by Widimsky et al. ${ }^{20}$ conducted in Europe between 2007 and 2008, 37\% to 93\% of STEMI patients received some kind of reperfusion treatment, varying from country to country, with primary $\mathrm{PCI}$ as the most prevalent therapy in most countries. ${ }^{21}$ In a study carried out in the United States between 2007 and 2009 with patients with infarction, primary PCI was adopted in $81 \%$ of the cases in which reperfusion treatment was applied. ${ }^{21}$

According to the ACCEPT trial, carried out in Brazil between 2011 and 2012, among the 846 patients admitted in hospital centers with STEMI, 83.3\% ( $\mathrm{n}=705)$ received reperfusion therapy, with $10 \%$ (71) being treated with thrombolytic agents and $90 \%$ (634) with primary angioplasty. ${ }^{22}$

Considering that the present study was a national analysis covering different tertiary care hospitals, the collected data indicate that $12.54 \%$ of the hospitalizations for STEMI treatment were for primary angioplasty, evidencing a possible contrast in relation to the ACCEPT trial.

Regarding mortality due to primary coronary angioplasty, Canadian studies analyzing data between 2000 and 2005 showed a mortality rate of $1.4 \% .^{19}$ Meanwhile, in North American studies carried out between 1998 and 2000, the mortality rate was $0.78 \%, 23$ whereas other studies conducted in the same country between 2004 and 2017 revealed a mortality rate of $1.27 \% .^{24}$ Data from Brazilian studies reported mortality rates between $2 \%$ and $6 \%,{ }^{11,25-30}$ however, the present study found national values close to $6.8 \%$.

In contrast with the findings commonly described in the literature regarding morbidity and mortality rates of the two main revascularization techniques, studies such as CAPTIM, in France, and WEST, in Canada, showed that the mortality rates in one year were not different between the groups of patients who received fibrinolytics and those who underwent primary PCI.
The two studies claim that participants who underwent fibrinolysis within two hours of symptom onset had better one-year survival when compared to those who received PCI in the same period; after two hours, no difference was observed. ${ }^{31}$

As for costs, although percutaneous angioplasty represented only $12.5 \%$ of hospitalizations for treatment of STEMI, the procedure corresponded to approximately $43.9 \%$ of the total expenses. However, the mortality rate in hospital admissions for primary angioplasty $(6.8 \%)$ was around $53.3 \%$ lower than for the treatment of STEMI (14.53\%). Therefore, it is possible to correlate primary PCI with lower mortality rates and higher costs. Nonetheless, we cannot rule out that discrepancy in these numbers may have been influenced by disparities in hospital centers.

The obtained data also showed that the mean length of stay of patients treated with angioplasty (5.3 days) was shorter than that registered for the treatment of STEMI (8.3 days). On the other hand, it is of note that the angioplasty procedure is more costly since it requires specific technologies and interventional cardiology team.

Regarding the relevance of hospitalizations for STEMI in the country, in the present study among the 1,895 types of procedures, the treatment of STEMI occupied significant positions in the national ranking of hospital admissions, costs, and deaths. The impact of cardiovascular diseases and, especially, STEMI on death rates and costs in Brazil is well established in the medical literature. In 2009, cardiovascular ischemic syndromes accounted for more than $7 \%$ of all deaths in the country and $19 \%$ of the total costs with hospitalizations in the SUS budget. ${ }^{13,32-34}$

It is important to highlight that there are several limitations regarding the quality of health services in Brazil, which may have influenced the use and effectiveness of different techniques, and hence on data obtained. Among these limitations, the following may be considered: different availability of hemodynamic laboratories; poor coordination of the health network; low efficacy of patient transport; and limited access or low availability of imaging tests, medications, resources, and technologies. ${ }^{34,35}$

Another aspect that can also be considered a limitation in this study was the dependence on data and designations attributed by the DATASUS platform to the analyzed categories. 


\section{Conclusion}

Based on the collected data, primary coronary angioplasty has been scarcely performed considering all the total number of hospitalizations for the treatment of STEMI. Despite the higher costs, the procedure promotes a shorter hospital stay and a lower mortality rate compared to other treatments for infarction. The significant increase in the use of primary angioplasty (by more than $49 \%$ in the past 10 years), concomitant with increases in the cases of STEMI, indicate that this alternative method can be further exploited in Brazil.

The statistical and epidemiological importance of data on STEMI hospitalizations, costs, and mortality rates can assist in measuring the impact of this disease on our society. Thus, the present study is of significant value for public health managers, as well as hospitals and medical teams that apply the PCI technique.

More studies in this field are needed in the country, considering particularities of each region and how health networks are organized to provide PCI for eligible patients in a timely manner and with qualified professionals. From an economic viewpoint, it would be interesting to compare PCI-related costs in Brazil with those in other countries where this technique has been used for a longer time to verify whether there is a trend of cost reduction with the advancement and greater accessibility of the technology required for this intervention.

\section{Potential Conflict of Interest}

No potential conflict of interest relevant to this article was reported.

\section{Sources of Funding}

There were no external funding sources for this study.

\section{Study Association}

This study is not associated with any thesis or dissertation work.

\section{Ethics approval and consent to participate}

This article does not contain any studies with human participants or animals performed by any of the authors.

\section{Author contributions}

Conception and design of the research: Minucci GS, Reis SM. Acquisition of data: Minucci GS, Reis SM. Analysis and interpretation of the data: Minucci GS, Reis SM. Statistical analysis: Minucci GS, Reis SM. Writing of the manuscript: Minucci GS, Reis SM. Critical revision of the manuscript for intellectual content: Minucci GS, Reis SM.

\section{References}

1. Bond MMK. O impacto da angioplastia coronariana prévia na cirurgia de revascularização do miocárdio: na morbimortalidade hospitalar, na qualidade de vida e sobrevivência em um ano.Tese. São Paulo: FMUSP, Instituto Dante de Pazzanese de Cardiologia.

2. Thygesen K, Alpert JS, Jaffe AS, Chaitman BR, Bax JJ, Morrow DA, et al. Fourth universal definition of myocardial infarction (2018). Eur Heart J. 2019; 40(3): 237-69.

3. Souza FNS, Nelson MVR, Gaglianone HC, Kuhn W, Macedo FS, Carvalho AAB (2019). Alterações Morfológica Cardíacas e Sistêmicas no Infarto Agudo do Miocárdio: Relato de Necrópsia. Revista de Patologia do Tocantins. 2019; 6(3): 3-7.

4. Piegas L, Timerman A, Nicolau JC,Mattos LA,Avezum A,et al. Sociedade Brasileira de Cardiologia. III Diretriz sobre tratamento do infarto agudo do miocárdio. Arq Bras Cardiol. 2004;83(Suppl 4):1-86.

5. Piegas LS, Timerman A, Feitosa GS, Nicolau JC, Mattos LAP, Andrade MD, et al.; Sociedade Brasileira de Cardiologia . V Diretriz da Sociedade Brasileira de Cardiologia sobre Tratamento do Infarto Agudo do Miocárdio com Supradesnível do Segmento ST. Arq Bras Cardiol. 2015;105(2 Suppl 1):S1-S121.

6. Nobre F, Serrano Junior CV. Tratado de cardiologia Socesp. São Paulo: Manole, 2005

7. Feres F, Costa RA, Siqueira D, Costa Jr JRC, Chamié D, Staico R, et al. Diretriz da sociedade brasileira de cardiologia e da Sociedade Brasileira

de Hemodinâmica e Cardiologia Intervencionista sobre intervenção coronária percutânea. Arq Bras Cardiol. 2020;109(1Suppl 1):S1-S81.

8. Feitosa GS, Feitosa-Filho GS, Barbosa P, Silva R, Pereira T, Pilar I, et al. O Tratamento Antiplaquetário por Via Oral na Doença Arterial Coronária-Visão Atual. RCHSI. 2019; 3(4): 203-17.

9. Pesaro AEP, Campos PCGD, Katz M, Corrêa TD, Knobel E. Síndromes coronarianas agudas: tratamento e estratificação de risco. Rev Bras Ter Intensiva. 2008; 20(2): 197-204.

10. Piegas LS, Bittar OJNV, Haddad N. Cirurgia de revascularização miocárdica: resultados do Sistema Único de Saúde. Arq Bras Cardiol. 2009; 93(5): 555-60.

11. Piegas LS, Haddad N. Intervenção Coronariana Percutânea no Brasil: resultados do Sistema Único de Saúde. Arq Bras Cardiol. 2011;96(4):317-24.

12. Mattos LA, Souza AGMR, Pinto IMF, Campos Neto CM, Labrunie A, Alves CR et al. Evolução temporal com a utilização da angioplastia coronariana primária no infarto agudo do miocárdio no Brasil: análise dos preditores de sucesso e dos eventos adversos hospitalares em 9.434 pacientes. Arq Bras Cardiol. 2002;79(4):405-11.

13. Barreto R, Cantarelli MJC, Castello Junior HJ, Gonçalves R, Gioppato S, Guimaraes JBF et al. Resultados da intervenção coronária percutânea primária em pacientes do sistema único de saúde e da saúde suplementar. Rev Bras Cardiol Invasiva. 2011; 19(3):279-65. 
14. Huynh T, Perron S, O'Loughlin J, Joseph L, Labrecque M, Tu JV, Théroux $\mathrm{P}$ et al. Comparison of primary percutaneous coronary intervention and fibrinolytic therapy in ST-segment-elevation myocardial infarction bayesian hierarchical meta-analysis of randomized controlled trials and observational studies. Circulation 2009;119(24):3101-9.

15. Keeley EC, Boura JA, Grines CL. Primary angioplasty versus intravenous thrombolytic therapy for acute myocardial infarction: a quantitative review of 23 randomised trials. Lancet. 2003; 361(9351):13-20.

16. O'gara PT, Kushner FG, Aschein DD, Casey Jr DE, Chung MK, Lemos JA et. al. ACCF/AHA Guideline for the Management of ST-Elevation Myocardial Infarction: A Report of the American College of Cardiology Foundation/American Heart Association Task Force on Practice Guidelines. Circulation. 2013;127(4):362-425.

17. Steng PF, James SK, Atar D, Badano LP, Blömstrom-Lundqvist C, Borger MA, et al. ESC Guidelines for the management of acute myocardial infarction in patients presenting with ST-segment elevation: The Task Force on the management of ST segment elevation acute myocardial infarction of the European Society of Cardiology (ESC). Eur. Heart J. 2012 Aug; 33(20): 2569-619.

18. Mattos LA, Lemos Neto PA, Rassi A Jr, Marin-Neto JA, Sousa AGMR, Devito FS, et al. Diretrizes da Sociedade Brasileira de Cardiologia Intervenção Coronária Percutânea e Métodos Adjuntos Diagnósticos em Cardiologia Intervencionista (II Edição - 2008). Arq Bras Cardiol. 2008; 91(6 supl.1):1-58.

19. Jamal SM, Shrive FM, Ghali WA, Knudtson ML; Eisenberg MJ. In-hospital outcomes after percutaneous coronary intervention in Canada:1992/93 to 2000/01. Can J Cardiol. 2003;19(7):782-9.

20. Widimsky P, Wijns W, Fajadet J, De Belder M, Knot J, Aaberge L et al. Reperfusion therapy for ST elevation acute myocardial infarction in Europe: description of the current situation in 30 countries. Eur Heart J. 2010; 31(8):943-57.

21. Peterson ED, Roe MT, Chen AY, Fonarow GC, Lytle BL, Cannon CP et al. The NCDR ACTION Registry-GWTG: transforming contemporary acute myocardial infarction clinical care. Heart. 2010; 96(22):1798-802.

22. Wang R, Neuenschwander FC, Lima Filho A, Moreira CM, Santos ESD, Reis HJL, et al. Uso de Intervenções Baseadas em Evidências na Síndrome Coronária Aguda-Subanálise do Registro ACCEPT. Arq. Bras Cardiol. 2014;102(4):319-26,

23. Hannan EL, Wu C, Walford G, King SB, Holmes DR Jr, Ambrose JA, et al. Volume-outcome relationships for percutaneous coronary interventions in the stent era. Circulation. 2005; 112(8):1171-9.

24. Peterson ED, Dai D, Delong ER, Brenann JM, Singh M, Rao SV, et al. NCDR Registry Participants. Contemporary mortality risk prediction for percutaneous coronary intervention: results from 588,398 procedures in the National Cardiovascular Data Registry. J Am Coll Cardiol. 2010; 55(18):1923-32

25. Oliveira LCS. Disparidades entre os serviços público e privado no uso de terapias de reperfusão para pacientes com IAMCSST: registro VICTIM. Aracaju. Tese. Sergipe: Universidade Federal de Sergipe; 2016.

26. Mallet ALR, Oliveira GMM, Klein CH, Carvalho MRM, Souza SNA Letalidade e complicações de angioplastias em hospitais públicos no Rio de Janeiro. Rev Saúde Pública. 2009; 43(6): 917-27.

27. Bienert IRC, Rodrigues A, Harada EA, Silva KL, Valente AR, Silva PA et al Avaliação Temporal dos Procedimentos de Revascularização Coronariana pelo Sistema Único de Saúde (SUS) no Brasil: Um Panorama de 20 Anos. Int J Cardiovasc Sci. 2017; 30(5): 380-90.

28. Cardoso CO, Quadros AS, Voltolini I, Azmus AD, Cardoso CR, Sebben $\mathrm{J}$, et al . Angioplastia primária no infarto agudo do miocárdio: existe diferença de resultados entre as angioplastias realizadas dentro e fora do horário de rotina?. Rev Bras Cardiol Invasiva. 2010; 18(3): 273-80.

29. Mattos LA, Souza AP, Ibraim MF, Campos Neto CDM, Labrunie A, Alves CR, Saad J. Evolução temporal com a utilização da angioplastia coronariana primária no infarto agudo do miocárdio no Brasil: análise dos preditores de sucesso e dos eventos adversos hospitalares em 9.434 pacientes. Arq Bras Cardiol. 2002; 79(4): 405-11.

30. Trevisol DJ, Bianchi BR, Sakae TM, Vinholes DB, Trevisol . Análise de sobrevida em pacientes submetidos à angioplastia coronariana com stent em um hospital da região sul de Santa Catarina. Scientia Medica. 2012; 22(2): 91-6.

31. Westerhout CM, Bonnefoy E, Welsh RC, Steg PG, Boutitie F, Armstrong $\mathrm{PW}$. The influence of time from symptom onset and reperfusion strategy on 1-year survival in ST-elevation myocardial infarction: a pooled analysis of an early fibrinolytic strategy versus primary percutaneous coronary intervention from CAPTIM and WEST. Am Heart J. 2011; 161(2), 283-90.

32. De Lima MSM, Dantas RAN, Dantas DV, Coutinho ICB, De Oliveira SP, Da Costa JM, et al. Trombólise no serviço pré-hospitalar móvel de emergência em vítimas de infarto agudo do miocárdio. Enferm Bras. 2019;18(1):109-15.

33. Teich V, Araujo DV. Estimativa de custo da síndrome coronariana aguda no Brasil. Rev Bras Cardiol. 2011;24(2):85-94.

34. Nicolau JC, Franken M, Lotufo PA, Carvalho AC, Marin Neto JA Lima FG, et al. Utilização de terapêuticas comprovadamente úteis no tratamento da coronariopatia aguda: comparação entre diferentes regiões brasileiras. Análise do registro brasileiro de síndromes coronarianas agudas (BRACE - Brazilian Registry on Acute Coronary Syndromes). Arq Bras Cardiol. 2012; 98(4):282-9.

35. Quadros AS. Intervenção coronária percutânea após trombólise no infarto agudo do miocárdio: para quem e quando?. Rev Bras Cardiol. Invasiva. 2011;19(4):355-6. 